Indian J Anim Health (2021), 60(2)-Special Issue:01-23

DOI: https://doi.org/10.36062/ijah.2021.spl.00421

\title{
Heavy metal poisoning and its impact on livestock health and production system
}

\author{
A. R. Gupta ${ }^{1}$, S. Bandyopadhyay ${ }^{2}$, F. Sultana ${ }^{1}$ and D. Swarup ${ }^{3 *}$ \\ ${ }^{1}$ Department of Veterinary Medicine Ethics and Jurisprudence, West Bengal University of Animal \\ and Fishery Sciences, Kolkata - 700 037, West Bengal, India; ${ }^{2}$ ICAR-IVRI, ERS, Kolkata - 700 \\ 037, West Bengal, India; ${ }^{3}$ Former Director, Central Institute for Research on Goats, Makhdoom, \\ Mathura 281 132, Uttar Pradesh, India
}

\begin{abstract}
Heavy metals are different from other toxic substances as they can be neither created nor destroyed. Anthropogenic activities are responsible for their redistribution into environment and exposure to man and animals. Biologically heavy metals are both beneficial and harmful. While a few heavy metals including copper, cobalt, iron, magnesium, manganese, selenium, and zinc are essential for vital physiological processes in trace amount, others like lead, cadmium and mercury are better known for their toxicities. Irrespective of their physiological role, all heavy metals when taken in excess than the tolerance limit are toxic. Animals are exposed to heavy metals via contaminated feed, fodder, forage and water mainly due to anthropogenic environmental pollution. Soils and water-bodies in certain geographic regions were found to carry excess concentration of heavy metals, which can be a natural source of poisoning in animals. Once consumed, heavy metals persist in the body for considerable time, and depending on the extent of exposure they induce acute or chronic; clinical or subclinical or subtle toxicities. Acute heavy metal poisoning is associated with typical clinical symptoms culminating into the death of an individual animal or a group of animals with similar necropsy findings. Chronic toxicities are characterized by detrition in general condition and loss in production. Presence of heavy metals above critical level in edible animal products is a cause of public health concern. Early diagnosis and specific antidote and management can effectively reduce the adverse impact of heavy metals on livestock health and production.
\end{abstract}

Key words: Animals, Health, Heavy metals, Production, Toxicity

\section{Highlights:}

- Heavy metal poisoning is one of the major non-infectious causes of adverse impact on animal health and production.

- Range of anthropogenic activities cause redistribution and elevated concentrations of heavy metals in the environment.

- Heavy metals bioaccumulate and persist in the body for considerable time, and can induce acute or chronic; clinical or subclinical or subtle toxicity.

- Presence of heavy metals above critical level in edible animal products is a cause of public health concern.

- Timely diagnosis, specific antidote therapy and management constitute the mainstay for early recovery.

\section{Introduction}

Animal husbandry is an age old practice and the livestock production system is an integral part of modern global economy. The production efficiency of animals is immensely influenced by their health status, which is often

impacted by a range of infectious and noninfectious diseases. Globally, livestock losses due to diseases were averaged above $20 \%$ (Justin et al., 2017). Heavy metal poisoning is one of the major non-infectious causes of

*Corresponding Author, E Mail: devendra.swarup@gmail.com 
adverse impact on animal health and production. Heavy metals are one of the oldest known toxicants to man due to their prehistoric use for diverse purposes. The Ebers papyrus (circa $1500 \mathrm{BC}$ ) contains information pertaining to many recognized poisons, including metals such as lead, copper, and antimony (Gallo, 2008). However the risk of exposure to heavy metals has increased considerably in the modern world due to their multiple industrial, domestic, agricultural, medical and technological applications (Tchounwou et al., 2012). In an analysis of the information on the occurrence of poisoning in livestock and poultry in the Europe, heavy metals were reported to be the second most significant factor causing mortality factor in accidental poisoning which corresponds to $34.4 \%$ of total positive cases in Northern Greece (Guitart et al., 2010). This article reviews current knowledge on some important aspects of heavy metal toxicities visà-vis animal health and production.

\section{Biological significance of heavy metals}

Heavy metals are the naturally occurring elements that have a high atomic weight and density, at least 5 times greater than that of water (Tchounwou et al., 2012). Knowledge and multi-purpose use of heavy metals predate recorded history of mankind and these metals have made critical contribution to the progress and success of civilizations. Owing to their extensive use and natural occurrence, the heavy metals are ubiquitous in the human environment causing some level of exposure to man and animals. In addition, all life has evolved in the presence of metals and organisms have been forced to deal with these potentially toxic, yet omnipresent, elements (Liu et al., 2008).

Heavy metals are both beneficial as well as harmful to the body and can be classified into four major groups based on their biological importance: essential, non-essential, less toxic and highly toxic heavy metals. Traces of heavy metals such as copper $(\mathrm{Cu})$, cobalt $(\mathrm{Co})$, manganese $(\mathrm{Mn})$, iron $(\mathrm{Fe})$, and zinc $(\mathrm{Zn})$ are essential for many vital physiological activities notably including regulation and function of several enzyme systems, oxygen and electron transport, synthesis of hormones, antioxidant defense, immunity and fertility. Deficiency of the essential metals not only adversely affects growth and physiological processes, but also potentiates toxicity due to non-essential heavy metals. Nonetheless, even essential metals will become toxic with increasing exposure. Toxic heavy metals, such as lead $(\mathrm{Pb})$, cadmium $(\mathrm{Cd})$ and mercury $(\mathrm{Hg})$ have no known beneficial biological role and are toxic even at very low concentrations (Anjulo and Mersso, 2015). Often the non-essential toxicant metals mimic essential metals and thereby gain access to, and potentially disrupt, key cellular functions. This can also account for bioaccumulation of toxic metals. Further, elemental nature of metals impacts their biotransformation and toxicity because detoxification mechanisms by destructive metabolism cannot break an atomic species into a subcomponent of less toxicity. In essence, being an element, metals are nonbiodegradable and this indestructibility along with bioaccumulation contributes to the high concern for metal as toxicant (Liu et al., 2008).

\section{Toxic metals in livestock and livestock production system}

Though heavy metals are neither created nor destructed by human endeavor, they are redistributed and concentrated into the environment from a range of anthropogenic activities mainly consisting of mining and metallurgy, foundries, burning of fossil fuel and vehicular emissions. Volcanic activity, metal evaporation from soil and water, metal corrosion, and sediment re-suspension, soil erosion, geological weathering are the natural sources of heavy metals exposure and toxicity to man and animals ( $\mathrm{He}$ et al., 2005; Tchounwou et al., 2012). Increased distribution of metals and metal compounds in the environment, especially through anthropogenic activities, raises increasing concern for ecotoxicological effects including toxicities in domestic animals. Biological cycles moving 
metals include bio-accumulation and biomagnification by plants and animals and their incorporation into food cycles (Liu et al., 2008). Heavy metal contaminants enter the food chain primarily through industry and agriculture (Tunegova et al., 2016). The coefficients of the transition and accumulation of heavy metals in the links of the food chain showed a strict correlation of animal welfare and dairy quality with environmental condition (Volkov and Samigullin, 2020).

Domestic animals share human environment and are exposed to heavy metals mainly via ingestion of contaminated vegetation, feed, water and soil and to some extent by inhalation of metal particles present in the air due to industrial and vehicular pollution. Pesticides, insecticides and fertilizers used in the agricultural field are the secondary source of heavy metal pollution for animals. Higher concentrations of heavy metals like copper and zinc have been reported in animal feeds which can be one of the major sources of these heavy metals to animals (Dweba et al., 2018). Once in the body, heavy metals generally conjugate with one or more bio-active ligands viz $-\mathrm{OH},-\mathrm{COO}^{-},-\mathrm{OPO}_{3} \mathrm{H}^{-},>\mathrm{C}=\mathrm{O},-\mathrm{SH}$, $-\mathrm{S}-\mathrm{S}, \mathrm{NH}_{2}$ and $>\mathrm{NH}$ that are essential for normal physiological function and activate several enzyme system and persist for considerable time (Klaassen, 1996). Persistence of heavy metals in animal body and surrounding environment has been recorded several weeks even after discontinuation of the exposure. Elevated levels of lead were detected in animal tissues up to 12-18 months after exposure had ceased. Higher blood lead burdens have been reported in animals including pets from urban localities and around polluting industrial units from various parts of India (Swarup et al., 2005). Further, the animals allowed to graze on or fed with contaminated pastures or fodders from industrial sources are continually exposed to toxic pollutants including heavy metals. Those animals can serve as the better indicator of the health impacts of toxic heavy metal pollution on human population than the toxicant-administered experimental subjects (Swarup et al., 2007).

\section{Toxic effects of heavy metals on domestic animals}

Toxic effects of heavy metals in animals depend on extent of exposure, type of heavy metal and its form, age, sex, physiological and nutritional status of exposed animal and route of poisoning. Most metals are concentrated in the vital organs including liver and kidney and cause clinical or subclinical toxicities or subtle effects like oxidative stress, immunotoxicity, cardiotoxicity teratogenicity, enzyme inhibition, reproductive defects and endocrine disruption (Swarup and Dwivedi, 2002). The precise chemical basis of metal toxicology is inadequately understood and there is no uniform mechanism for all toxic metals because of the great variation in chemical properties and toxic endpoints (Liu et al., 2008). It is true that being elements, heavy metals are nonbiodegradable. However, their forms may be changed to free metal ions thereby altering their biological availability, activity and consequently, toxicity (Hollenberg, 2010). Chemically, metals in their ionic form can be very reactive and can interact in biological systems with toxicological targets in a large variety of ways resulting in variety of toxic effects and damage to various organs including kidney, nervous system, liver, respiratory system, endocrine and reproductive systems and gastrointestinal tract. The targets of heavy metals are generally cellular molecules, macromolecules, membranes or organelles and the toxicity is initiated by interaction of free metal ions with these targets. Common mechanisms by which toxic metals may act include inhibition of enzymes, subcellular organelles, interaction with DNA leading to mutagenesis and carcinogenesis, covalent modification of proteins, displacement of other critical metals dependent proteins, and generation of free radicals (Hollenberg, 2010). On the basis of their toxic effects, Kozlowski et al. (2014) placed toxic metals in four groups- 
metals (copper and iron) acting as Fenton reaction catalyst and participate in generation of free radicals and oxidative stress; carcinogenic metals (nickel, cadmium, and chromium); metals (aluminum, lead and tin) involved in neurotoxicity; generally toxic metals like mercury. However, there is growing volume of literature suggesting that majority of heavy metals are capable of inducing oxidative stress in different animal species including buffalo (Yeotikar et al., 2018) and affects the oxidative stress quotient (Roth, 2017; Abuelo, 2019). Overproduction of free radicals and oxidative stress, not only affect immunity, but also cause biological disorders resulting in many diseases via damaging biomolecules, subcellular compartments and even whole cell e.g. neurons (Kozlowski et al., 2014). Production and reproductive performance of farm animals is heavily influenced by oxidative stress which may be responsible for considerable economic losses. Toxic heavy metals potentially disrupt endocrine system and can influence production and reproductive performance of animals (Swarup et al., 2007).

There are growing evidences that heavy metals can influence antibiotic resistance and heavy metal induced co-selection of antibiotic resistance genes (ARGs) has become an emerging environmental issue (Ding et al., 2019). Presence of heavy metals such as arsenic, copper and zinc even at low level in the environment has been found to enhance resistance of bacterium to tetracycline (Chen et al., 2015). Livestock and livestock production system are viewed as the large reservoir of heavy metals due to their use in feed as well as exposure to heavy metal contaminants in the environmental. As such cocontamination of heavy metals and antibiotics in the livestock environment can add to the rapidly growing concern of antibiotic resistance. The proven positive correlation of heavy metal resistance and coexisting methicillin-resistance Staphylococcus aureus (MRSA) highlights the vulnerabilities of both humans and animals as compounded resistance is particularly difficult to treat effectively (Dweba et al., 2018).

\section{Heavy metal contamination of animal products and food safety concern}

Heavy metals are usually nonbiodegradable and tend to accumulate in the food chain including edible animal products like meat and milk of exposed livestock populations. Significant amount of heavy metals can be transferred from contaminated soil, water and air to plants and grass, causing accumulation of these metals in grazing animals and subsequently their transfer to food chain via milk and meat. Thus accumulation of toxic metals in animals is not only associated with toxic effects in food producing animals, but also poses health risks to humans consuming milk and meat contaminated by the toxic metals.

Milk is not the major route of excretion of lead and cadmium. However, milk lead concentration is exponentially related to blood lead. As such, milk from lactating animals reared around industrial sources is expected to contain higher concentration of lead with possible risk of public health hazard (Swarup et al., 2000). There are several reports from different parts of the world indicating higher concentration of heavy metals in milk of cows reared in the contaminated environment (Vromman et al., 2008; Cai et al., 2009; Gonzalez-Montana et al., 2012; Pilarczyk et al., 2013; Rahimi, 2013). In Iran, $1.9 \%$ of the bovine and $8.1 \%$ of the sheep milk samples were found to contain higher levels of lead than the newly established Codex Standard indicating its public health hazards (Rahimi, 2013). Presence of lead in edible animal products like milk (Swarup et al., 2005; Kambli et al., 2019), chevon (Kar et al., 2015) and poultry meat (Orisakwe et al., 2017) is also reported in India raising public health concern. There are also reports indicating the presence of arsenic in cow milk, particularly in arsenic affected parts of the country (Rana et al., 2008). Likewise, a study from the same area revealed high concentration of arsenic in poultry products like 
chicken and poultry eggs. Contamination of heavy metals like cadmium and mercury was pointed out by another study conducted in Haryana (http://epubs.icar.org.in/ejournal/ index.php/IJDS/article/view/87447). More information on this aspect is reviewed under the description of specific toxicities associated with toxic heavy metals.

A comprehensive review providing information on toxic doses, concentration in tissues of poisoned animals and physiological effects, symptoms, diagnostic procedures and treatment for poisoning by cadmium, lead, copper, chromium, iodine, manganese, molybdenum, selenium and zinc in the animals has been published by Reis et al. (2010). It is noted that old, young, undernourished and stressed farm animals are more severely affected and overall impact depends on kind of toxic metal and extent of exposure. General aspects of toxicity caused by some heavy metals of veterinary importance are reviewed hereunder.

Arsenic toxicity: Arsenic (As), referred as 'Poison of Kings and the King of Poisons', is one of the earliest known poisons to ancient civilizations. It was often used as secret poison by the royal people as symptoms of arsenic poisoning were camouflaging. Egyptians used arsenic for decoration in Egyptian tombs (Liu et al., 2008) and Alchemists used it for transformation of other metals into gold. Arsenic was also widely used for treatment of several diseases during the 18th, 19th, and early 20 th centuries. The medicinal use of arsenic has however declined with introduction of more effective and safe drugs. In modern time arsenic is known more for its toxic potential than medicinal properties (Swarup and Dwivedi, 2011).

Exposure to arsenic can occur due to its redistribution into the environment from several anthropogenic activities mainly including mining and metallurgy, and use of arsenic for domestic purposes. The industrial arsenic toxicity is not new as it finds mention in the ancient records. Theophrastus of Erebus (370-
287 BC) and Pliny the Elder (23-79 AD) described the pernicious effects of arsenic and mercury on miners and smelters (Hollenberg, 2010). Anthropogenic activities that release arsenic into environment include copper, lead and zinc smelting (Klaassen, 1996), burning of coal containing naturally high levels of arsenic (Liu et al., 2008) and wood treated with arsenical preservatives (Khan et al., 2006).

Sources of As exposure to domestic animals include contamination of pastures from copper and lead smelters, arsenic-containing herbicides and pesticides and veterinary use of arsenicals as dipping and spraying of animals, feed additives, growth promoters, antidotes for selenium poisoning, and in the control and treatment of animal dysentery. Metal bearing ores and arsenic contaminated ground water are the natural sources of As to animals (Constable et al., 2017). The presence of high concentrations of inorganic arsenic in ground water has been well documented in many countries of the world including India, Vietnam, Cambodia, Bangladesh, Taiwan, Argentina, Japan, Thailand, Chile, Mongolia, Finland and Hungary. An extensive 28 year field survey (1988-2016), conducted in India, found high concentration $(>10 \mu \mathrm{g} / \mathrm{L})$ of As in more than 170,000 tube-well water samples collected from states of West Bengal, Bihar, Uttar Pradesh, Jharkhand, Assam, Manipur and Chhattisgarh. The signs of chronic arsenic toxicity were found in more than $10 \%$, of the 100,000 people screened (Chakraborti et al., 2016). The livestock populations sharing the human environment in these areas may also be exposed to toxic levels of arsenic very similar to human beings. Apart from contaminated drinking water, large number of animals in arsenic affected areas ingests arsenic contaminated grasses, feed stuffs, vegetables and rice plants, which can be the potential source of As exposure (Mandal, 2017). In a recent study in arsenic endemic areas of Bihar, the contribution of food to As exposure to human population was found to be almost equal (median value $=49 \%$ ) to that of drinking water 
(median value 51\%). Importantly, contribution of food to As exposure was more than drinking water even though the water level of As was more than provision value recommended by the WHO (>10 $\mu \mathrm{g} / \mathrm{L})$ (Mondal et al., 2021). However, such information on the arsenic exposure to animals via contaminated feed and fodder in As endemic areas are limited, necessitating further studies to investigate contribution of different sources to over-all exposure of animals to As in endemic areas and subsequent transfer of the toxic metal in food chain through animal products.

Toxic profile of arsenic is complicated. Chemically arsenic occurs in organic and inorganic forms with +3 or +5 valence. Trivalent inorganic arsenicals (arsenites) are 10 times more toxic than pentavalent inorganic arsenicals (arsenate). However, the toxicity depends on other factors also such as particle size, the solubility and purity of arsenic compounds, species and general health of animals. The order of toxicity from the greatest to the least is as: inorganic trivalent As (arsenite) $>$ organic pentavalent As (arsenate) $>$ trivalent organics $>$ pentavalent organics. After absorption, arsenic is accumulated in liver and is slowly distributed to the other tissues. The spleen, kidneys and lungs also accumulate large concentration of arsenic (Garland, 2012). Tissues rich in oxidative enzyme system are primarily affected. Alimentary tract, liver, kidney, spleen, and lungs are mostly affected leading to general depression of metabolic activity and development of clinical signs (Constable et al., 2017).

In India, reports on clinical arsenic toxicity in animals are rare, even from the arsenic affected areas, where elevated level of As were reported in milk, blood and hair of cattle, possibly due to the reason that surface water is the main source of drinking water for animals (Nandi et al., 2005). Clinical signs representing arsenic toxicity are considered to be symptoms of gastrointestinal tract, cardiovascular and nervous system abnormalities. Abdominal pain, restlessness, respiratory distress, grinding, ruminal stasis, and even vomiting are seen in acute cases. Inorganic arsenic toxicity in beef calves leads to clinical signs of lethargy, ataxia, anorexia and diarrhea followed by death (Faires, 2004). Meta-analysis of 156 cases from 16 outbreaks of acute arsenic toxicity in cattle showed that the most common clinical sings were death (68\%), diarrhea (33\%), ataxia (29\%), dehydration (22\%) and respiratory stress (4\%). The most common clinicopathological abnormalities included azotemia (100\%), haematuria $(100 \%)$, increased liver enzyme activity (86\%) and increased haematocrit (60\%). The study concluded that although acute arsenic toxicity in cattle has a poor prognosis, survival is possible provided aggressive fluid therapy and antidotes are administered (Bertin et al., 2013). Chronic arsenic toxicity is mostly manifested in weight loss, capricious appetite, conjunctival and mucosal erythematic lesions including mouth ulceration, and reduced milk yield in cows. The haemato-biochemical changes in subclinical arsenic poisoning in cattle from an arsenic contaminated zone included significantly high concentration of arsenic in blood, low haemoglobin, total erythrocyte count and plasma proteins, and increased level of alanine amino-transaminase and aspartate amino-transferase enzymes along with decrease superoxide dismutase and catalase activities in erythrocytes (Rana et al., 2010).

Quantification of arsenic in tissues and stomach content is standard laboratory test for diagnosis of arsenic. Liver is the best organ for diagnosis of acute poisoning, whereas kidney may contain high concentration of arsenic in subacute or chronic poisoning (Constable et al., 2017). Normal levels of arsenic in liver and kidneys of animals are $<1 \mathrm{ppm}$ (wet basis). In cases of toxicity, levels exceed $3 \mathrm{ppm}$. Urine samples may contain high arsenic content for several days after exposure (Swarup and Dwivedi, 2011). Diagnostic value of arsenic in urine and faces is $10-20 \mathrm{mg} / \mathrm{kg}$ (Constable et al., 2017). Analysis of hair and urine samples is useful for monitoring As exposure and 
diagnosis of chronic poisoning in animals. In an arsenic endemic area the concentration of arsenic in hair and urine samples of cattle ranged between 0.245 and $0.69 \mathrm{ppm}$, and 0.461 and $0.984 \mathrm{ppm}$, respectively. A close relationship was observed between arsenic concentration in water with that of urine $\left(r^{2}=0.03668, p<0.05\right)$ and hair $\left(\mathrm{r}^{2}=0.03668, \mathrm{p}<0.05\right)$ concentrations indicating that the arsenic quantification in hair and urine can serve as a biomarker for arsenic exposure to livestock (Bera et al., 2010). In general, bio-concentration factor (BCF) and biotransfer factor (BTF) are useful to evaluate the subclinical toxicity in animals as they do not exhibit clinical toxicity like human being.

Prognosis in acute arsenic poisoning is poor. However, early diagnosis and aggressive fluid and antidotal treatment can effectively reduce mortality (Bertin et al., 2013). British Antilewisite (BAL, 4-7 mg/kg intramuscular thrice a day for 2-3 days) has been traditionally used as an antidote in clinical toxicity. Thioctic acid may be used alone or in combination with BAL. Other chelating agents such as 2, 3 Dimercaptopropane-1-sulphonate (DMPS), Dimercaptosuccinic acid (DMSA) and Dpenicillamine have been found more effective and comparatively less toxic (Swarup and Dwivedi, 2011). Treatment of chronic As toxicity by sodium thiosulfate in cows resulted in reduction of arsenic load in milk (Ghosh et al., 2011). Mixture of $\mathrm{Zn}$ and $\mathrm{Se}$ is considered useful in the management of As toxicity (Dash et al., 2013). Recently, certain medicinal herbs have been reported to ameliorate the toxic effects of arsenicosis (Hazarika et al., 2015; Biswas et al., 2017; Maji et al., 2020).

Lead toxicity: Lead is bluish white grey heavy metal, which is perhaps the first toxic element recognized by man and yet still has great relevance today. Although increased regulations on use of lead have decreased the use of lead products, the poisoning due to lead in animals is recorded with greater frequency than any other metal (Thompson, 2012). Historically, because of its easy malleability, great resistance to weather and low melting point, the metal has been mined since antiquity. As early as 7000- 5000 BC, Egyptians used lead for glazing pottery. The ancient civilizations of Phoenicia, Greece, China and India also used lead for vessels, roofs, water ducts, utensils, ornaments and weights. The ancient Romans were the first to explore industrial potential of lead and used it extensively in the transport of water to such an extent that it gave to genesis to the modern word plumber, which is used for persons involved in fitting of water supply (Swarup and Dwivedi, 2011). Romans also used lead for glazing potteries and many more purposes giving lead the status as Roman metal to lead (Hamir, 1986). Perhaps Romans were also the first to have suffered from lead toxicity.

Lead poisoning has been reported from allover the world, almost in all species of livestock, pigs and goats being the most tolerant. Cattle, particularly young calves are more susceptible. Owing to their natural curiosity, licking habits, and indiscriminate eating habit, cattle can ingest lead bearing objects present in their environment as domestic, industrial or agricultural wastes and can suffer suffer from accidental acute lead poisoning (Constable et al., 2017). Besides natural exposure from soils or earth crust with high content of lead, the toxic metal enters the food chain of farm animals through contaminated soil, feed and water from anthropogenic sources like burning of fossil fuels, smelting, mining and alloy processing, combustion of coal, paint industries, leaded batteries, textile and other lead based industries (Swarup et al., 2005). Lead contamination of grazing areas beside highways from vehicular emissions has reduced considerably after introduction of unleaded fuel. However, lead is still found in pastures nearby highways. The pastures adjacent to heavily used roads have been reported to carry as much as 390 ppm lead, which decreases rapidly with increasing distance from highways and lower vehicular traffic (Constable et al., 2017). Presence of discarded 
lead based batteries in grazing areas has caused several incidences of lead poisoning in cattle. Empty paint tins and machinery grease are other important source of lead poisoning in animals (Uppal, 2004). Lead poisoning can be a major hazard in the vicinity of oil fields, and engine sump oil may contain over $500 \mathrm{mg}$ lead per $100 \mathrm{~mL}$. Automotive and other mineral oils are very palatable to young beef calves and thus, they are more likely to suffer (Constable et al., 2017). However, as lead use becomes restricted in many countries, risk of acute poisoning in cattle has reduced due to grease and leadcontaminated engine oil (Burren et al., 2010). Contamination of vegetation and pastures nearby secondary lead smelters (battery recycling units) and lead-zinc smelter (Dey et al., 1996; Dwivedi et al., 2001) was the source of acute lead toxicity in cattle and buffaloes, and subclinical toxicity in goats affecting essential trace mineral profile (Swarup et al., 2006).

Toxic effects of lead depend on its chemical form, dose and duration of exposure and the species of animals. Organic lead compounds are, in general, more readily absorbed in the body than either inorganic lead salt or metallic form of lead and thus are more toxic (Thompson, 2012). Young, old and undernourished animals with dietary deficiencies of essential minerals are more susceptible. Cattle are more prone to contract poisoning due to their inherent eating habit, hungry cattle can consume anything and their chances of ingestion of lead bearing objects are very high (Swarup and Dwivedi, 2002).

After absorption lead is distributed to different organs mainly bone, kidney, and liver. It can cross blood-brain and also the placental barriers and can be accumulated in brain and fetus of exposed animals. The liver and kidneys of fetus of a lead poisoned pregnant heifer contained 0.425 and $4.84 \mathrm{ppm}$ lead, respectively, which was $72 \%$ and $84 \%$ of the lead concentrations in the respective organs of the dam (Constable et al., 2017). Bone is the sink for lead and onset of clinical toxicity due to chronic exposure to lead occurs when the lead level crosses saturation in the natural sink.

A significant correlation was reported between level of lead excreted in milk and that in blood in cows in an industrial locality. It was noted that the excretion of lead through milk increases when the blood lead was $>0.20$ $\mu \mathrm{g} / \mathrm{mL}$ (Swarup et al., 2005). This may be a potential risk to human health as milk is a regular component of human diet and contaminated milk may contribute to daily intake of lead above the maximum permissible limit. In a study, buffaloes that had suffered from acute industrial plumbism were found to excrete high level of lead $(1.13 \pm 0.38 \mathrm{ppm})$ in milk after 6 weeks of exposure discontinuation (Dey et al., 1996). It is suggested that blood lead level should be monitored once or twice monthly for several months for treated animals before they are allowed for slaughter. The meat is considered safe for consumption when blood lead levels drop to background levels for three consecutive sampling at least three weeks apart (Sharpe and Livesey, 2006). However, decisions to withholding milk or meat for human consumption depend on national food safety regulations and economic aspects.

In the body, lead affects several physiological processes of the animal body leading to neurotoxicity, gastrointestinal damage, oxidative stress, kidney and liver dysfunctions, inhibition of enzyme system associated with synthesis of haemoglobin and calcium and vitamin D metabolism, endocrine disruption, and other cellular alterations (Swarup and Dwivedi, 2002; Fennie et al., 2011; Patra et al., 2011; Constable et al., 2017; Slivinska et al., 2020). Clinical manifestations in lead poisoning are mainly due to its toxic effects on gastrointestinal tract, the central nervous system and haemopoietic systems. Central nervous system involvement is seen in up to $90 \%$ of lead poisoned cases, where as $60 \%$ cases show gastrointestinal problems (Krametter-Froestscher et al., 2007).

Cattle often suffer from acute signs of lead poisoning consisting of gastrointestinal and 
neurological disturbances marked by anorexia, bellowing, dullness, blindness and head pressing. Convulsions, opisthotonus and coma also occur in severe cases. If these severe clinical signs are missed, lead poisoning can appear as a sudden death. Longer term, fertility can be impaired (Bates and Payne, 2017). Similar clinical signs have been reported in buffaloes in acute lead poisoning caused due to industrial pollution (Dwivedi et al., 2001). Gastrointestinal symptoms in lead poisoned cattle include diarrhea, cramping, abdominal distension and pain. In sub-acute lead toxicity, signs of dullness, anorexia, depression, loss of weight and eye sight, incoordinations, staggering and sometimes circling are seen for a period of four to five days followed by death of the animal. Lead also affects the reproductive system causing negative impact on production (Verma et al., 2020). Natural exposure of lactating cows to lead from nearby lead-zinc smelter is reported to alter hormonal and essential trace mineral profiles, which may adversely affect their reproductive and production performance (Swarup et al., 2007). It was found that cows with blood lead level $>0.60 \mu \mathrm{g} / \mathrm{mL}$ had significantly $(\mathrm{P}<0.05)$ lowered blood copper and iron (Patra et al., 2006).

Most findings indicate comparatively higher tolerance in sheep and goats to toxic metals like lead and cadmium than cattle. Sheep excrete higher concentration of lead, chromium and nickel in their excrements than cows (Makridis et al., 2012). This may be a reason for comparatively higher lead concentrations in milk of ewes than cows. Sheep mostly show subacute toxicity that simulates signs of lead toxicity in adult cattle (Swarup and Dwivedi, 2011; Constable et al., 2017). In a study, lead exposure in sheep and cattle grazing on an old mining area, indicated greater susceptibility of cattle than sheep and only $13.5 \%$ sheep as compared to $91.4 \%$ of cattle exhibited elevated lead levels corresponding to subclinical lead exposure (Rodríguez-Estival et al., 2012).

Goats, though comparatively more tolerant to lead (chronic toxicity dose $400 \mathrm{mg}$ per $\mathrm{kg}$ body weight) than cattle and sheep, can also exhibit cumulative lethal toxicity with predominant sign of CNS involvement following long duration exposure to lead (Swarup and Dwivedi, 2002). Incidence of combined lead and cadmium toxicity is also reported in goats raised within $5 \mathrm{~km}$ radius of a cement kiln. The animals exhibited locomotor disturbances, ranging from a stiff gait to complete posterior paralysis. Lead was the primary cause of toxicity as the contaminated soil $(890 \pm 43.01 \mathrm{ppm})$ and forages $(420 \pm 153.94$ ppm) contained higher concentrations of lead. The diagnosis was based on the significantly higher concentration of lead in blood $(0.511+0.12 \mathrm{ppm})$ in goats raised in polluted area than those $(0.085+0.016 \mathrm{ppm})$ raised in the control environment (Oluokun et al., 2007).

Interaction between trace and toxic metals is well known and exposure to lead is reported to influence the macro and trace mineral composition in blood, milk and other tissues thus affecting the quality and nutritive value of meat and milk. Importantly, lead mimics calcium and zinc at cellular level, which is suggested to be one of the mechanisms of neuropathy. Sewage sludge is an important source of heavy metal contamination of pasture. Sheep and lambs raised on the pastures fertilized for 5 years with sewage sludge showed an elevated level of lead along with lower levels of copper and zinc concentrations in liver. The mean concentrations of lead, cadmium and nickel were approximately two to four folds higher in ewe than lamb's liver while mean copper concentrations were approximately five fold lower in ewes. This pattern suggested influence of prolonged exposure on accumulation of toxic metals and their subsequent effects on essential micronutrients like copper (Rhind et al., 2005).

Inhibition of $\delta$-aminolevulinic acid dehydratase (D-ALAD) enzyme not only causes lead-associated anaemia but also contributes to decreased oxygen carrying capacity to the nervous system resulting tissue ischaemia (Constable et al., 2017). Lead 
induced oxidative stress can be associated with damage to lipids, proteins and DNA (Lawton and Donaldson, 1991; Patra et al., 2011). A significant increase in malondialdehyde (MDA) level, indicative of oxidative stress has been reported in cows with blood lead concentration of $0.58 \pm 0.06 \mathrm{ppm}$ (Dhaliwal and Chabra, 2016).

Level of lead in heparinized blood, kidney and liver are the best indicators of lead poisoning (Traverso et al., 2004). The normal lead values in ruminants ranged between 0.05 and $0.25 \mathrm{ppm}$ in whole blood and upper limit for lead in liver is fixed at $1 \mathrm{ppm}$. A high blood and high fecal lead indicates current exposure and a high blood and low fecal lead is indicative of past exposure. Poisoned animals have blood lead concentration above $0.35 \mathrm{ppm}$. However, there are reports on survival of buffaloes despite having more than $1 \mathrm{ppm}$ lead in blood (Dey et al., 1996; Dwivedi et al., 2001). Since blood lead has been reported to fluctuate after administration of lead, indirect tests like $\delta$ aminolevulinic acid dehydratase and plasma $\delta$ aminolevulinic acid have been suggested as sensitive biomarkers of lead poisoning (Kang et al., 2010; Rodríguez-Estival et al., 2012; Constable et al., 2017). Higher lead residues are found in blood and tail hair of cows reared around lead-zinc smelter and closed lead cum operational zinc smelter. The hair lead levels showed significant positive correlation with blood lead concentration suggesting that tail hair can also be useful to monitor lead residues in animal system (Patra et al., 2007).

Management of lead toxicity involves identifying the source and preventing further exposure by removing it or by moving the cattle away, providing supportive care to exposed cattle with chelation therapy, if practical, and ensuring that issues associated with food safety are addressed (Bates and Payne, 2017). Calcium disodium-EDTA (calcium versenate) is an effective antidote for lead poisoning and has been used successfully in cattle, horse, and sheep. However, it is not without side effects and renal and gastrointestinal toxicities may occur with long term therapy (Constable et al., 2017). A combination therapy comprising thiamine hydrochloride along with Ca-EDTA has shown better efficacy in resolving clinical signs both in experimental and field cases of lead poisoning (Swarup and Dwivedi, 2002). Successful management of lead poisoning was reported by using a therapeutic approach comprising of Ca-EDTA @ $110 \mathrm{mg} / \mathrm{kg}$ body weight alongside antibiotics, NSAIDs, rumenotorics, tonics and intravenous fluid therapy (Singh, 2018). Cathartics like magnesium sulfate have proven to be useful in removing lead from the GI tract (Assi et al., 2016). Although animals with less severe clinical signs can recover, tissue lead concentrations can remain elevated for months to years posing a potential issue with lead residues in the food chain (Bates and Payne, 2017).

Mercury toxicity: Mercury $(\mathrm{Hg})$ is a naturally occurring element found in elemental, inorganic/organic forms and in various oxidation states in the environments. Mercury or quicksilver had long been used by Indians and Chinese as a traditional medicine and also in many allopathic formulations like diuretics, antibacterial, antiseptics, skin ointment and laxatives. The other sources of mercury are plastics (vinyl chloride), chlor-alkali (in the manufacture of chlorine and caustic soda), electrical (electrical switches and fluorescent light) and electronic batteries. The effluents from these industries served as a source of mercurial contamination of marine ecosystem and food chain with associated adverse impacts on the aquatic and terrestrial life including man and animals (Nicholson et al., 1983).

Presently mercury is widely understood for its toxic potential posing a global threat. It was listed as one of the ten leading chemicals of concern by the World Health Organization in 2017 (Raj and Maiti, 2019). The last century witnessed several incidences of mercury poisoning due to pollution causing death of man and animals in Japan, Guatemala, Iraq and 
Pakistan. 'Mina- Mata disease', one of the worst industrial disasters that occurred due to dumping of mercury, is a classic example of ecotoxicity due to mercury affecting various animal species and man in a food-web. The disease, officially discovered in 1956 in Japan, was caused by the contamination of marine ecosystem with mercury, which was present in the effluent of a plastic manufacturing unit. The less toxic inorganic mercury compound present in the effluent was converted to highly toxic organic compounds by aquatic organisms resulting into the contamination of the entire food chain involving fish, birds, cats and man (Harda, 1978). Elevated levels of mercury in the biota due to industrial pollution have been also reported in India. An estuary ecosystem and surrounding area of a chloralkali industry was found to contain high mercury concentration (Mishra et al., 2013).

Mercury poisoning is rare in domestic animals, but accidental acute or chronic poisoning can occur following ingestion of organic mercury or inorganic compounds (Schmitz, 2007). Oral ingestion of organic mercury present in the form of phenyl-mercury in the treated grains may be a more common source of cumulative chronic poisoning (Bilandzic et al., 2010). However, ration containing up to $10 \%$ of treated grains was not harmful; even feeding of a single large amount grains was incapable of causing toxicity in ruminants. The clinical illness may occur in cattle only when large amount of grains are fed for a long periods. Sporadic cases of poisoning in horses can occur due to accidental administration of drugs containing mercury and licking or cutaneous absorption of skin dressing containing mercuric oxide (Constable et al., 2017).

Emissions and wastes from thermal power plants, chlor-alkali plants, paper pulp mills, cement manufacturing units, cinnabar ore smelting units contribute to environmental contamination with mercury and other heavy metals, and animals in surroundings of these industrial units are likely to be exposed to the pollutants. Coal combustion in thermal power plants is the major anthropogenic source of mercury and from there, it can be bioaccumulated in plants and moves into food chain resulting in potential health risks to man and animals (Raj and Maiti, 2019). In a study, lactating cows reared within $5 \mathrm{~km}$ radius of a thermal- power station had significantly higher levels of mercury in blood $(7.41 \pm 0.86 \mu \mathrm{g} / \mathrm{kg})$, milk $(4.75 \pm 0.57 \mu \mathrm{g} / \mathrm{kg})$ and in urine $(2.08 \pm 0.18$ $\mu \mathrm{g} / \mathrm{kg}$ ). The exposed cows showed significantly reduced haemoglobin levels, and elevated values of blood urea nitrogen, serum creatinine, albumin and serum glutamate oxaloacetate transaminase indicating impacts of mercury on animal health. The study concluded that long term exposure of the cows to fly ash mercury may have direct or indirect impact on human population via food chain (Mahajan et al., 2012).

Toxic effects of mercury depend upon chemical form of mercury, the dose, duration and route of exposure and species of animals (Gupta, 2012). Cattle are highly susceptible, with toxicity occurring on an average daily intake of $10 \mathrm{mg}$ organic mercury/kg body weight. In sheep toxic effects can be seen with intake of $17.4 \mathrm{mg} / \mathrm{kg}$ body weight, whereas in horse chronic ingestion of inorganic mercuric chloride $(0.8 \mathrm{gm} / \mathrm{kg}$ body weight for 14 weeks) resulted in mercury toxicity (Constable et al., 2017).

Gastrointestinal tract is the main route of absorption of mercury and comparatively organic compounds are absorbed more rapidly than the inorganic compounds. Major target of toxicity to inorganic and organic mercury are the kidneys and CNS, respectively (Gupta, 2012). Once in the body, mercury is accumulated chiefly in proximal convoluted tubular part of kidneys. Organic mercury can cross blood brain and placental barriers, and accumulates in brain and fetus. It is distributed to other tissues and excreted very slowly primarily through feces and to some extent in urine and milk. Meat, liver and kidneys from animals poisoned by mercury are unsuitable for 
human consumption. Milk is also unsafe depending on the form of mercury poisoning (Constable et al., 2017). Presence of high amount of mercury in cottage cheese (Singh et al., 2019) has been reported from Haryana state (Kumar et al., 2019) and in the vicinity of Mumbai (Kambli et al., 2019).

Clinical signs of mercury toxicity in livestock vary greatly and are attributable to damage caused to gastro-intestinal tract, kidneys, and CNS. Experimental studies in animals showed that mercury in form of organic compounds is neurotoxic and adversely affects the nervous system of animals even at lower concentration without any harmful effect on other systems (Ceccatelli et al., 2010; Gupta, 2012). Inorganic mercury causes corrosive effects on gastro-intestinal mucosa with signs of vomition, diarrhea and colic. It can cause renal damage when ingested in large quantities. However, the inorganic mercury does not readily cross blood brain barriers and as such neurotoxicity is unlikely in cases of inorganic mercury poisoning. Signs of acute poisoning in cattle include blindness, excitement, behavioral changes, incoordination and convulsions and death. Average time from ingestion to death is reported to be about 20 days (Gupta, 2012). Clinical signs of poisoning in sheep are similar to cattle. In horse signs like peripheral neuropathy, (laryngeal hemiplegia), laminitis, intermittent colic, and acute renal failure are common (Casteel, 2001).

In experimental animals, mercury is found to cause adverse impact on male reproductive system, on developing fetus and induces spontaneous abortions and still birth. Experimental studies have also proved that mercury can cause potential mutagenic, carcinogenic and immunotoxic effect. Severe disruption of the antioxidant system was evident from experimental studies carried out on mechanisms of mercury toxicity (Yang et al., 2020). Mercury has a great affinity to selenium and binds to this site in selenoproteins of the thioredoxin system and the glutathioneglutaredoxin system resulting in imbalance of antioxidant environment and proliferation of intracellular reactive oxygen species (Spiller, 2018). It is reported that oxidative stress caused by long-term exposure to mercury impairs endothelial function and increase risks of cardiovascular diseases and also damages blood brain barriers causing neuropathy (Takahashi and Shimohata, 2019). Signal transduction, protein or/and enzyme activities and gene regulation are affected as result of toxic and adaptive responses to mercury exposure (Yang et al., 2020).

Mercury levels in whole blood, urine, liver, kidney, brain and hair are of diagnostic significance. Kidney is an ideal source from dead animals. Tissue concentration above 5 ppm is suggestive of clinical toxicity. The whole blood or hair values are used to determine exposure to methylmercury, whereas urine is useful to determine inorganic mercury. Blood mercury levels provide more useful information about recent exposure than long term exposure. It is recommended to test hair, blood and urine samples together to predict possible health impacts caused by different forms of mercury (Gupta, 2012).

Treatment of mercury poisoning involves use of chelators. Meso-2,3-dimercaptosuccinic acid (DMSA) and 2,3-dimercapto-propanesulphonate (DMPS) are new chelators that have effectively mobilized deposits of mercury into the urine in such cases. These drugs when administered orally have showed relatively low toxicity compared to the classical antidote dimercaptopropanol (BAL) (Cao et al., 2015). The supplementation of selenium in the diet provides substantial protection against inorganic and organic mercury toxicity in poultry (Ekino et al., 2007). Selenium and mercury are mutual antagonist and there is an emerging evidence that the pathophysiological target of mercury is in fact due to its inhibitory effect on selenium rather than on the ubiquitous sulfhydryl group. Mercury is known to produce selenium deficiency and a direct inhibition of selenium controlled intracellular redox environment. Selenium supplementation, with 
limitations, may have a beneficial role in restoring adequate selenium status from the deficiency state and mitigating the toxicity of mercury via multifaceted mechanisms (Spiller, 2018). On the basis of current knowledge combined approach focusing on restoration of selenoprotein function, reduction of oxidative stress and increased excretion of mercury has been suggested for management of poisoning. The role of selenium includes restoration of selenoproteins, protection against mitochondrial injury and DNA damage, demethylation of organic mercury, sequestering of mercury via $\mathrm{Hg}$-Se complexes and redistribution of mercury from brain (Spiller et al., 2021).

The application of phytoremediation techniques has emerged as a proven approach to remove mercury from contaminated soil and thus reducing the risk of contamination of food chain including livestock system. Plant species such as Brassica juncea are potential candidates for mercury removal from soil (Raj and Maiti, 2019). More multidisciplinary studies are required on management of mercury toxicity and understanding mechanisms of different treatment approaches.

Cadmium toxicity: Cadmium $(\mathrm{Cd})$ is an element with soft, ductile, silvery white with bluish color, lustrous, and electropositive properties. It is considered as an extremely toxic metal with destructive impact on most organ system (Bernhoft, 2013). Cd reaches in the environment from both natural and anthropogenic sources. Natural sources of cadmium are mineral ores, volcanic activity, weathering of Cd-containing rocks, and forest fires (Yost, 1984). Cadmium is released in combination with lead and zinc and/or other metals from non-ferrous metal smelters and processing facilities (Hooser, 2018). Combustion of fossil fuels, waste incineration (especially Cd-containing batteries and plastics), and manufacture of phosphate fertilizers are the other sources of Cd (Mennear, 1979; Hardman and Limbird, 1996). It is usually found as an impurity in zinc and lead deposits and therefore can be a byproduct of zinc and lead smelting. Other sources include industrial pollution from zinc smelters, mining wastes, coal combustion, and water from old zinc- or cadmium-sealed pipes (Bernhoft, 2013). Cadmium oxide and cadmium anthranilate are used as anthelmintic for treatment of ascariasis in pigs. Shampoos containing cadmium sulphide may cause toxicity to animals (Sandu and Brar, 2003). Use of rock phosphate fertilizers and leakage of sewage sludge to agricultural soil may cause contamination of soil with cadmium and its transfer to plants and further to food chain (Rahimzadeh et al., 2017). Domestic animals are also exposed to cadmium mainly via ingestion of contaminated herbages grown over contaminated soils or in the vicinity of cadmium emitting industrial units. Cadmium is mobile in plants and may become concentrated in leaves; therefore grazing animals may potentially receive the highest exposure to the element (Madejón et al., 2009). Cadmium toxicity in domestic animals is rather rare, but exposure to cadmium is gradually increasing, especially in grazing animals by ingestion of cadmium taken up by plants (Hooser, 2018). The exposed animals are reported to carry higher body burden of cadmium. In a study from Croatia,the European Union, maximum concentration in kidney were exceeded by $92.3 \%$ of horses $(0.029-47.4 \mathrm{mg} / \mathrm{kg}), 14 \%$ of cattle and by $16 \%$ of sheep (Bilandzic et al., 2010). In another study from China, cattle in the area around a lead-zinc smelter had higher level of cadmium in kidneys $(38 \mathrm{mg} / \mathrm{kg})$ and liver $(2.5 \mathrm{mg} / \mathrm{kg})$. The cadmium levels in soil $(10 \mathrm{mg} / \mathrm{kg})$ and feed $(6.6 \mathrm{mg} / \mathrm{kg})$ was 10 times higher than Chinese standards (Cai et al., 2009). Water from deep wells may also carry high quantity of cadmium in certain areas (Pérez-Carrera et al., 2016).

Presence of cadmium has been reported in edible animal products. Meat with traces of cadmium is considered health hazard (Kar et al., 2015; Orisakwe et al., 2017). Hazardous levels of cadmium, exceeding the Food and Agricultural Organization and World Health 
Organization permissible limit, were reported in liver, kidneys and muscles of cattle and sheep in Egypt due to environmental pollution and this might pose human health risks (Darwish et al., 2015). Higher levels of cadmium have also been recorded in chicken meat (Orisakwe et al., 2017), cattle fodder, milk and meat (Sathyamoorthy et al., 2016), milk products like curd, cheese, khoa and milk powder (Singh et al., 2019).

After absorption, cadmium is rapidly accumulated in kidneys and liver (Ali, 2001; Patra et al., 2007). It readily binds to and induces production of metallothionein, a cysteine rich metal binding protein. This, in part, facilitates retention of cadmium in cell and its long half-life [estimated to be $>10 \mathrm{yr}$ in humans] (Hooser, 2018). It inhibits essential enzymes in Kreb's cycle, and affects cell proliferation, differentiation and apoptosis. These activities interact with DNA repair mechanisms, the generation of reactive oxygen species (ROS) and induction of apoptosis. Induction of oxidative stress is the major pathway of cadmium toxicity. It involves binding of cadmium to sulfhydryl group of protein, depletion of reduced glutathione, and enhanced production of ROS via inhibition of antioxidant enzymes such as copper- zinc- manganese superoxide dismutase, and catalase (Rahimzadeh et al., 2017).

Not much information is available on clinical course of frank cases of cadmium toxicity in different species of livestock under field conditions. Very often, cadmium is released along with lead from different industrial sources; as such the clinical signs in spontaneous poisoning are amalgamation of the two metals. In cattle and sheep, cadmium levels in the feed greater than $50 \mathrm{mg} / \mathrm{kg}$ dry matter are associated with toxicity (Reis et al., 2010). Accidental ingestion of large amount of cadmium causes acute nephrotoxicity and liver damage. Chronic ingestion is associated with accumulation of the metal in different body organs mainly the kidneys, liver, lungs, and testes in animals. Clinical signs in cattle include inappetence, weakness, loss of weight, poor hoof keratinization, dry brittle horns, matting of the hair, keratosis. Prominent necropsy lesions comprised of hyperkeratosis of forestomach epithelium and degenerative changes in most organs (Constable et al., 2017). Vascular degeneration and necrotic changes in liver, kidneys and lungs are reported in cattle and buffaloes from an industrial area and often had tissue cadmium levels $>2 \mathrm{ppm}$ (Gumasta et al., 2018). Experimental poisoning of sheep by administration of cadmium @ $2.5 \mathrm{mg}$ per $\mathrm{kg}$ body weight resulted in anaemia, nephropathy, and bone demineralization. Other potential effects are abortion, congenital defects and stillbirths. Cadmium level in the feed @ 50 $\mathrm{mg} / \mathrm{kg}$ for 6 weeks caused reduced growth rate and an iron-responsive anemia in piglets. Horses develop lameness and swollen joints with osteoporosis and nephrocalcinosis (Constable et al., 2017).

Apart from overt toxicities, exposure to cadmium is associated with subclinical and subtle effects mainly including oxidative stress, immunotoxicity, endocrine disruption, reduced reproductive performance, poor body weight gain and altered micronutrient profile (Swarup and Dwivedi, 2002). Long-term exposure to cadmium increases lipid peroxidation and causes inhibition of superoxide dismutase activity indicating oxidative damage in liver, kidney and testes (Patra et al., 1999). In an experimental study, feeding of young cattle with cadmium@0.04 mg/kg body weight resulted in decrease in both enzyme and nonenzyme antioxidant protection (Gutyj et al., 2017).

Animals deficient in calcium, iron and zinc are more prone to cadmium toxicity (Alonso et al., 2004). Selenium administration protects the liver (Newairy et al., 2007) and kidney (El-Sharaky et al., 2007) in cases of cadmium toxicity. Administration of diets with high levels molybdenum concentration (Smith and White, 1997; Alonso et al., 2004) and iron (Groten et al., 1991; Alonso et al., 2004) prevented signs of cadmium poisoning. 
Copper toxicity: Copper is an essential trace element required for various physiological functions as cofactor in several enzyme systems in the body. However, it can be extremely toxic when present in excess. Incidences of copper poisoning are recognized in farm animals, either due to intake of excess copper (primary copper poisoning or copper toxicosis) or due to other factors influencing intake, metabolism, and excretion of the element (secondary copper poisoning or toxemic jaundice), particularly in ruminants who lack efficient regulatory mechanisms for copper (Constable et al., 2017). Among the ruminants, sheep is the most susceptible species to chronic copper poisoning and cases of poisoning have been reported worldwide. Cattle, on the other hand, were traditionally thought to be relatively more tolerant to copper accumulation, and reports of copper poisoning in cattle were somewhat rare until recently. However, number of copper poisoning and associated fatalities are also rising worldwide, especially in dairy cattle (LópezAlonso and Miranda, 2020).

Primary copper poisoning occurs when animals ingest excess amount of copper than required. Acute toxicity is reported after injection or ingestion of single large dose of copper compounds, whereas chronic poisoning is associated with accumulation of small amount of copper over long period (NRC, 2005; Reis et al., 2010). Farm animals may be exposed to excess copper from several agricultural and industrial activities as well animal husbandry and veterinary practices. Accidental ingestion or administration of copper containing substances such as copper sulfate foot-bath and copper containing fungicides/algaecides, and prophylactic injection of copper salts may be associated with acute toxicities (Constable et al., 2017). Copper poisoning due to excessive nutritional supplementation is an important cause of jaundice, haemoglobinuria and death in semi-confined cattle (Martin et al., 2020). Copper, arsenic and chromium are used as preservative, and ash produced from burning of treated wood and insulation products can be dangerous for domestic animals (Hoff et al., 1998). Copper mining and smelters, plants grown over soil fertilized with copper, feeding seed grains treated with copper containing antifungals, copper rich salt licks, mineral supplements and commercial milk replacers, copper containing boluses, pastes, needles or wires placed in the rumen, and grazing pastures contaminated from top-dripping from overhead cable and immediately after top-dressing with copper containing compounds are the other sources of excess copper for animals (Constable et al., 2017). An outbreak of copper poisoning in cattle was associated with feeding litter from poultry that had been fed a ration treated with copper sulfate to avoid aspergillosis (Tokarnia et al., 2000).

The ingested copper is accumulated in the liver for a variable period without clinical signs and toxicity. A sudden release of massive amount of copper from liver store increases the blood copper concentration causing lipid peroxidation and intravascular haemolysis with resultant toxicity (Blakley, 2005). Conditions such as acute and, particularly, chronic copper exposure along with defects in hepatic copper metabolism, altered excretion of copper, and nutritional imbalances between copper and other trace elements, stress including transportation and pregnancy, strenuous exercise, malnutrition can lead to release of copper from hepatic stores resulting in primary copper toxicosis (Bozynski et al., 2009). Low level of molybdenum in the diet can cause copper toxicity even when the amount of copper is appropriate (Fuentealba and Aburto, 2003).

Toxicity of copper depends on species of farm animals. Ruminants are more susceptible due to their poor homeostatic control over copper absorption and consequently they have developed mechanisms for storing excess copper in liver by decreasing copper in liver. However, when exposed to copper levels higher than physiological requirement, they fail to modulate their excretion ability and may suffer from copper poisoning (NRC, 2005; Suttle, 
2012). Acute poisoning may occur following intake of 20-100 mg copper per kg bodyweight in sheep and young calves and after 200-800 mg copper per $\mathrm{kg}$ bodyweight in adult cattle. Chronic poisoning in sheep may occur with daily intake of $3.5 \mathrm{mg}$ copper per $\mathrm{kg}$ when their grazing pasture contains $15-20 \mathrm{ppm}$ copper (DM) and low level of molybdenum (Gupta, 2018). Amongst ruminant species, goats can tolerate much higher dietary copper intake (640 $\mathrm{mg}$ per $\mathrm{kg}$ bodyweight, DM), and their copper requirements (15-25 $\mathrm{mg}$ per $\mathrm{kg}$ bodyweight) are much higher than sheep. High tolerance of goats to copper may be explained by lower hepatic uptake in goats. Goats can also tolerate higher amount of copper antagonist molybdenum than sheep and cattle, without suffering secondary copper deficiency (López-Alonso and Miranda, 2020). Non-ruminant animals including horse and pigs are relatively resistant. Toxic doses for horse are $125 \mathrm{mg}$ copper per $\mathrm{kg}$ bodyweight (acute), and $791 \mathrm{mg}$ per $\mathrm{kg}$ bodyweight for 6 month (chronic). Chronic copper toxicity in pigs may occur@200-500 mg copper per kg bodyweight (NRC, 2005; Constable et al., 2017). There is also variation of copper requirement within species as several factors like composition of ration; breed and husbandry practices influence the copper metabolism including absorption. The absorption coefficient of copper could also be substantially reduced in pasture fed animals as ingestion of soil reduces copper absorption (López -Alonso and Miranda, 2020). Cattle and buffaloes are reported to be equally susceptible to chronic copper poisoning. However, buffaloes accumulate less liver copper than cattle, and have a lower threshold of copper accumulation, which leads to clinical manifestation of poisoning (Minervino et al., 2009). Published literature also indicates breedrelated difference in copper metabolism and susceptibility to copper poisoning in cattle and sheep.

Most frequently observed clinical signs in acute copper poisoning are anorexia, abdominal pain, diarrhea, dehydration, incoordination, salivation, and collapse prior to death, usually within 24 hours. Surviving animals develop icterus and dysentery (Reis et al., 2010). Ascites, hydrothorax, haemoglobinuria, head pressing, opisthotonus, aimless wandering, bruxism, circling and ataxia are reported in calves surviving for 3 or more days (Fazzio et al., 2012). Chronic poisoning is a haemolytic disease. Affected sheep show anorexia, thirst, depression, jaundice, haemolytic anaemia, and haemoglobinuria along with increased respiratory and pulse rate. Nervous signs marked by depression, blindness, tetraparesis are also seen in sheep (Giadinis et al., 2009). Classical signs of chronic copper poisoning noted in cattle and buffaloes, following administration of increasing doses of copper (2-28 mg per $\mathrm{kg}$ bodyweight) for 105 days, included haemoglobinuria, apathy, disorderly gait, reduced ruminal movements, severe dehydration, icteric mucus membrane, mild diarrhea, and oliguria. However, classical signs of icterus and haemoglobinuria were not observed in 3 of the 12 experimental animals. Surviving animals showed progressive hyporexia and weight loss. The clinical manifestations were more severe in buffaloes than cattle (Minervino et al., 2009).

Chronic copper poisoning is usually associated with decrease in production and adaptation ability to environmental conditions. Excess of copper influences the reproductive performance in ewes probably by affecting the endometrium and the hypothalamus-pituitaryaxis. It could also cause a dysfunction of estrogen receptors resulting in reproductive disorders and pathology of pregnancy on various levels of the reproductive axis. Supplementation of copper (25-50 mg per animal) over the recommended dietary levels in ewes affected the fecundity and prolificacy as well as loss of fetuses before day 90 of the pregnancy (Murawski et al., 2006).

Diagnosis of copper poisoning is made on the estimation of tissue copper concentration and biochemical parameters. Serum copper concentration and ceruloplasmin are the two most frequently used parameters for diagnosis of copper poisoning in live animals. However, the direct estimation of copper in liver biopsy is the 
best method for detecting chronic subclinical copper accumulation in cattle (López-Alonso et al., 2006). Liver function tests, especially liver specific enzyme activities, are useful for diagnosis and patient monitoring. But liver function cannot be tested in dead animals and cupremia changes to values within normal range. Also the liver copper concentration in fatal cases may not be of much value, because there is no longer copper accumulation period in the liver as occurs in chronic copper poisoning. Estimation of kidney copper concentration in the renal cortex is suggested as a useful parameter for post-mortem acute copper poisoning diagnosis (Fazzio et al., 2012). In general copper-loaded or intoxicated animals can be effectively diagnosed by analysis of copper concentration in liver and kidneys supported by clinical and necropsy findings. Normal values of copper vary from one laboratory to other. A range of 200-500 ppm wet weight in liver and 5-7 ppm in kidney indicates high level of copper in cattle. The toxic levels of copper in liver and kidney in cattle are $>250 \mathrm{ppm}$ and $10 \mathrm{ppm}$, respectively. In sheep toxic levels of copper are $>250 \mathrm{ppm}$ in liver and $>18 \mathrm{ppm}$ in kidneys. A value of $>230 \mathrm{ppm}$ of copper wet basis in liver is suggestive of toxicities in goats (Dalefield, 2017).

Different chelating agents and molybdenum therapies have been used to treat $\mathrm{Cu}$-loaded or intoxicated animals (Humphries et al., 1986; Gooneratne and Christensen, 1997; Mecitoglu et al., 2017). Copper antagonists may be supplemented in the diet of the animal in the area with high risk of copper poisoning. Dietary supplementation with molybdenum and sulfur has been useful in preventing the disease (Antonelli et al., 2016). Treatment with $200 \mathrm{mg}$ per cow per day of sodium molybdenum for 7 days reduced copper concentration in liver by $50 \%$ and prevented further mortality in a herd of lactating cows that was suffering from chronic copper poisoning due to excess copper supplementation (Barel et al., 2019). Zinc supplementation@300 mg/kg DM was found effective in preventing excessive hepatic copper accumulation in sheep exposed to high dietary concentrations of copper (Minervino et al., 2018). Replacement of copper rich supplements and sources of copper for animals is an essential practice.

\section{Conclusion}

Heavy metals can enter in animals through natural and anthropogenic sources. Though some heavy metals are essential to maintain biochemical and physiological functions, all heavy metals exhibit their toxic effects via metabolic interference and mutagenesis. The principal way of removal of heavy metals should be the prevention of heavy metals entering the animal body. Phytoremediation and intercropping are ways in which heavy metals can be absorbed and removed from the animal environment. Once heavy metals enter the body, some entero-absorbents may be used to chelate them. Supplementation of some medicinal herbs in animal diet can aid to the gradual removal of metals from the body. Oxidative stress induced via different mechanisms and altered redox potential is one of the common pathways of heavy metal toxicity and inclusion of antioxidants in therapeutic regimen can substantially reduce toxic effects. More studies are suggested on toxico-epidemiology, toxicokinetics, especially identification of molecular targets of heavy metals and novel therapeutic approaches to management of poisoning in different species of animals in the back drop of current advancement in toxicology.

Conflict of interest: Authors have no conflict of interest in this study.

Author's contribution: ARG: Manuscript preparation and literature collection; SB: Manuscript editing and bibliography preparation; FS: Data analysis, draft and revision of the manuscript; DS: Lead of the project, conception and design of the article and interpretation of the relevant literature, manuscript editing. 


\section{REFERENCES}

Abuelo A, Hernández J, Benedito JL and Castillo C, 2019. Redox biology in transition periods of dairy cattle: role in the health of periparturient and neonatal animals. Antioxidants, 8(1): 20, doi: 10.3390/antiox 8010020

Ali SL, 2001. Alleviation of cadmium induced oxidative stress, nephrotoxicity and thyroid dysfunction in sheep. PhD thesis submitted to Division of Medicine, Indian Veterinary Research Institute, Izatnagar, India

Alonso ML, Mantaña FP, Miranda M, Castilho C, Hernández $\mathrm{J}$ et al., 2004. Interactions between toxic (As, $\mathrm{Cd}, \mathrm{Hg}$ and $\mathrm{Pb}$ ) and nutritional essential (Ca, $\mathrm{Co}, \mathrm{Cr}, \mathrm{Cu}, \mathrm{Fe}, \mathrm{Mn}, \mathrm{Mo}, \mathrm{Ni}, \mathrm{Se}, \mathrm{Zn}$ ) elements in the tissues of cattle from NW Spain. Biometals, 17(4): 389-397, doi: 10.1023/ B:BIOM.0000029434.89679.a2

Anjulo TK and Mersso BT, 2015. Assessment of dairy feeds for heavy metals. Am Sci Res J Eng Technol Sci, 11(1): 20-31

Antonelli AC, Barrêto Junior RA, Mori CS, Minervino AHH, Schalch UM et al., 2016. Use of molybdenum rich mineral mix in the prevention of cumulative cooper poisoning in sheep - hepatic microminerals. Arq Bras Med Vet Zootec, 68(3): 629-635, doi: 10.1590/1678-4162-8738

Assi MA, Hezmee MN, Haron AW, Sabri MY and Rajion MA, 2016. The detrimental effects of lead on human and animal health. Vet World, 9(6): 660671, doi: 10.14202/vetworld.2016.660-671

Barel S, Cuneah O, Sharir B, Koren U, Edery N et al., 2019. First case of chronic copper toxicosis in dairy cows in Israel and its remedial Management. Isr J Vet Med, 74(1): 39-43

Bates N and Payne J, 2017. Lead poisoning in cattle. Livestock, 22(4): 192-197, doi: 10.12968/ live.2017.22.4.192

Bera AK, Rana T, Das S, Bhatacharya D, Bandyopadhyay S et al., 2010. Ground water arsenic contamination in West Bengal, India: A risk of sub-clinical toxicity in cattle as evident by correlation between arsenic exposure, excretion and deposition. Toxicol Ind Health, 26(10): 709716, doi: 10.1177/07482337 10377775

Bernhoft RA, 2013. Cadmium toxicity and treatment. Sci World J, 2013: 394652, doi: 10.1155/2013/ 394652

Bertin FR, Baseler LJ, Wilson CR, Kritchevsky JE and Taylor SD, 2013. Arsenic toxicosis in cattle: MetaAnalysis of 156 cases. J Vet Intern Med, 27(4): 977-981, doi: 10.1111/jvim.12124
Bilandzic N, Dokic M and Sedak M, 2010. Survey of arsenic, cadmium, copper, mercury and lead in kidney of cattle, horse, sheep and pigs from rural areas in Croatia. Food Add Contam, 3(3): 172-177, doi: 10.1080/19440049.2010.503194

Biswas S, Maji C, Sarkar PK, Sarkar S, Chattopadhyay A et al., 2017. Ameliorative effect of two Ayurvedic herbs on experimentally induced arsenic toxicity in calves. J Ethnopharmacol, 197: 266-273, doi: 10.1016/j.jep.2016.07.079

Blakley BR, 2005. Copper poisoning. In: The Merck Veterinary Manual 9th edn. CM Kahn (ed.) Merck \& Co. Inco., N. J. USA. pp 2353-2355

Bozynski CC, Evans TJ, Kim DY, Johnson GC, HughesHanks JM et al., 2009. Copper toxicosis with hemolysis and hemoglobinuric nephrosis in three adult Boer goats. J Vet Diagn Invest, 21: 395-400, doi: $10.1177 / 104063870902100319$

Burren BG, Reichmann KG and Mckenzie RA, 2010. Reduced risk of acute poisoning in Australian cattle from used motor oils after introduction of lead-free petrol. Aust Vet J, 88(6): 240-241, doi: 10.1111/ j.1751-0813.2010.00577.x

Cai Q, Long ML, Zhu M, Zhou QZ, Zhang L et al., 2009. Food chain transfer of cadmium and lead to cattle in a lead-zinc smelter in Guizhou, China. Environ Poll, 57(1): 3078-3082, doi: 10.1016/ j.envpol.2009.05.048

Cao Y, Skaug MA, Andersen O and Aaseth J, 2015. Chelation therapy in intoxications with mercury, lead and copper. J Trace Elem Med Biol, 31: 188192, doi: 10.1016/j.jtemb.2014.04.010

Casteel SW, 2001. Metal toxicosis in horses. Vet Clin North Am Equine Pract, 17(3): 517-527, doi: 10.1016/S0749-0739(17)30049-4

Ceccatelli S, Dare E and Moors M, 2010. Methylmercury induced neurotoxicity and apoptosis. Chemo biol Interact, 188: 301-308, doi: 10.1016/ j.cbi.2010.04.007

Chakraborti D, Rahman MM, Das B, Chatterjee A, Das D et al., 2016. Groundwater arsenic contamination and its health effects in India. Hydro J, 25(4): 1165-1181

Chen S, Li X, Sun G, Zhang Y, Su J et al., 2015. Heavy metal induced antibiotic resistance in bacterium LSJC7. Int J Mol Sci, 16(10): 23390-23404, doi: 10.3390/ijms 161023390

Constable PD, Hinchcliff KW, Done SH and Grunberg W, 2017. Veterinary Medicine: A Textbook of Diseases of Cattle, Horses, Sheep, Pigs and Goats. $11^{\text {th }}$ edn., Elsevier Ltd. Missouri, pp 421-425 
Dalefield R, 2017. Veterinary Toxicology for Australia and New Zealand. Elsevier Ltd, pp 233-236

Darwish WS, Hussein MA, El-Desoky KI, Ikenaka Y, Nakayoma $\mathrm{S}$ et al., 2015. Incidence and public health risk assessment of toxic metal residues (cadmium and lead) in Egyptian cattle and sheep meats. Int Food Res J, 22(4): 1719-1726

Dash J, Datta B, Sarkar S and Mandal TK, 2013. Chronic arsenicosis in cattle: possible mitigation with $\mathrm{Zn}$ and Se. Ecotoxicol Environ Safety, 92: 119-122, doi: 10.1016/j.ecoenv.2013.03.003

Dey S, Dwivedi SK and Swarup D, 1996. Lead concentration in blood, milk and feed of lactating buffalo after acute lead poisoning. Vet Rec, 138(14): 336, doi: 10.1136/vr.138.14.336-a

Dhaliwal RS and Chabra S, 2016. Effects of heavy metals on oxidative stress parameters of cattle inhabiting Buddha Nallah area of Ludhiana district in Punjab. J Vet Sci Technol, 7(5): 1-3, doi: 10.4172/21577579.1000352

Ding J, An XL, Lassen SB, Wang Ht, Zh D et al., 2019. Heavy metal-induced co-selection of antibiotic resistance genes in the gut microbiota of collembolans. Sci Total Environ, 683: 210-215, doi: 10.1016/j.scitotenv.2019.05.302

Dweba CC, Zishiri OT and El Zowalaty ME, 2018. Methicillin resistant Staphylococcus aureus: livestock-associated antimicrobial, and heavy metal resistance. Infect Drug Resist, 11: 2497-2509, doi: 10.2147/IDR.S175967

Dwivedi SK, Swarup D, Dey S and Patra RC, 2001. Lead poisoning in cattle and buffalo near primary leadzinc smelter in India. Vet Human Toxicol, 43(2): 93-94

Ekino S, Susa M, Ninomiya T, Imamura Kand Kitamura T, 2007. Minamata disease revisited: An update on the acute and chronic manifestations of methyl mercury poisoning. J Neurol Sci, 262(1-2): 131144, doi: 10.1016/j.jns.2007.06.036

El-Sharaky AS, Newairy AA, Badreldeen MM, Eweda SM and Sheweita SA, 2007. Protective role of selenium against renal toxicity induced by cadmium in rats. Toxicol, 235(3): 185-193, doi: 10.1016/j.tox.2007.03.014

Faires MC, 2004. Inorganic arsenic toxicosis in a beef herd. Can Vet J, 45(4): 329-331

Fazzio LE, Mattioli GA, Costa EF, Picco SJ, Rosa DE et al., 2012. Renal cortex copper concentration in acute copper poisoning in calves. Pesq Vet Bras, 32(1): 1-4, doi: 10.1590/S0100-736X201 2000100001

Fennie JW, Windsor PA and Kesell AE, 2011.
Neurological diseases of ruminant livestock in Australia II. Toxic disorders and nutritional deficiencies. Aus Vet J, 89(7): 247-253, doi: 10.1111/j.1751-0813.2011.00793.x

Fuentealba IC and Aburto EM, 2003. Animal models of copper-associated liver disease. Comp Hepatol, 2(1): 5-17, doi: 10.1186/1476-5926-2-5

Gallo MA, 2008. History and scope of toxicology. In. Cassarett and Doull's Toxicology. The Basic Science of Poisons. C D Klassen. Ed. $7^{\text {th }}$ edn., McGraw-Hill, New York, pp 3-11

Garland T, 2012. Arsenic. In: Veterinary Toxicology: Basic and Clinical Principles. RC Gupta Ed. Academic Press, pp 499-502

Ghosh CK, Datta BK, Biswas S, Maji C, Sarkar S et al., 2011. Chronic arsenicosis of cattle in West Bengal and its possible mitigation by sodium thiosulfate. Toxicol Int, 18(2): 137-139, doi: 10.4103/09716580.84266

Giadinis ND, Papaionnoy N, Kritsepi-Konstantinou M, Roubies N, Raikos N et al., 2009. Acute encephalopathy and clinical pathology findings in a sheep with chronic copper poisoning. Turkish J Vet Anim Sci, 33(4): 363-366, doi: 10.3906/vet-0809-21

Gonzalez- Montana JR, Senis E, Gutierrez A and Prieto F, 2012. Cadmium and lead in bovine milk in milk in the mining area of the Caudal River (Spain). Environ Monit Assess, 184(7): 4029-4034, doi: 10.1007/s10661-011-2241-1

Gooneratne SR and Christensen DA, 1997. Effect of chelating agents on the excretion of copper, zinc and iron in the bile and urine of sheep. Vet J, 153: 171-178, doi: 10.1016/S1090-0233(97)80037-8

Groten JP, Sinkeldam EJ, Muys T, Luten JB and Bladeren $\mathrm{PJ}, 1991$. Interactions of dietary $\mathrm{Ca}, \mathrm{P}, \mathrm{Mg}, \mathrm{Mn}, \mathrm{Cu}$, $\mathrm{Fe}, \mathrm{Zn}$ and $\mathrm{Se}$ with the accumulation and oral toxicity of cadmium in rats. Food Chem Toxicol, 29(4): 249-258

Guitart R, Croubels S, Caloni F, Sachana M, Davanzo F et al., 2010. Animal poisoning in Europe. Part 1: Farm livestock and poultry. Vet J, 183(3): 249-254, doi: 10.1016/j.tvj1.2009.03.002

Gumasta P, Dubey A, Swamy M and Verma Y, 2018. Study on cadmium associated microscopic lesions in cattle and buffaloes. Indian J Vet Path, 42(4): 303-306, doi: 10.5958/0973-970X.2018.00069.X

Gupta RC, 2012. Mercury. In: Veterinary Toxicology: Basic and Clinical Principles. RC Gupta Ed. Academic Press, pp 537-543

Gupta RK, 2018. A review of copper poisoning in animals: sheep, goat and cattle. Int J Vet Sci Anim Hus, 3(5): 1-4 
Gutyj B, Stybel V, Darmohray L, Lavryshyn Y, Turko I et al., 2017. A prooxidant- antioxidant balance in the organism of bulls (young cattle) after using cadmium load. Ukrainian J Ecol, 7(4): 589-596, doi: 10.15421/2017_165

Hamir AN, 1986. Review of lead poisoning in dogs. Vet Bull, 56: 1059-1070

Harda M, 1978. Methyl mercury poisoning (Minamata disease). In: Toxicity of heavy metals in the environment. Pt I. FW Oehme (ed), Marcel Dekkar Inc. New York, pp 261-302

Hardman JG and Limbird LE, 1996. Goodman and Gillman's the pharmacological basis of therapeutics. 9th Ed, McGraw-Hill Health Professions Division. pp 1662-1664

Hazarika JM, Sarkar PK, Chattopadhyay A, Mandal TK and Sarkar S, 2015. Evaluation of some selected herbs on arsenic-affected cattle in Nadia District, West Bengal, India. Environ Sci Pollut Res Int, 22(7): 4942-4948, doi: 10.1007/s11356-014-3863-y

He ZL, Yang XE and Stoffella PJ, 2005. Trace elements in agroecosystems and impacts on the environment. J Trace Elem Med Biol, 19: 125-140, doi: 10.1016/ j.jtemb.2005.02.010

Hoff B, Boermans HJ and Baird JD, 1998. Retrospective study of toxic metal analyses requested at a veterinary diagnostic toxicology laboratory in Ontario (1990-1995). Canadian Vet J, 39: 39-43

Hollenberg PF, 2010. Introduction: Mechanisms of metal toxicity special issue. Chem Res Toxicol, 23: 292-293, doi: 10.1021/tx900456p

Hooser SB, 2018. Cadmium. Veterinary Toxicology $3^{\text {rd }}$ edn., Academic Press, pp 417-421

Humphries WR, Mills CF, Greig A, Roberts L, Inglis D et al., 1986. Use of ammonium tetrathiomolybdate in the treatment of copper poisoning in sheep. Vet Rec, 119(24): 596-598

Justin DD, Hunt L, Filho KE, Ritten J, Capper J et al., 2017. Livestock production systems. In Rangeland Systems: Processes, Management and Challenges. David D Briske (Ed) Springer Open, pp 347-372

Kambli A, Sole S, Garud K, Lonare S and Bagal N, 2019. Quantitative analysis of toxic metals in buffalo milk samples from Mumbai suburban region by ICP_AES. J Anim Health Prod, 7(1): 5-10, doi: 10.17582/journal.jahp/2019/7.1.5.10

Kang HG, Bischoff K, Ebel JG, Cha SH, McCardle J et al., 2010. Comparison of blood lead and blood and plasma d-amino-levulinic acid concentrations as biomarkers for lead poisoning in cattle. $\mathrm{J}$ Vet Diagn Invest, 22: 903-907, doi: 10.1177/10406387 1002200608
Kar I, Mukhopadhayay SK, Patra AK and Pradhan S, 2015. Metal concentrations and histopathological changes in goats (Capra hircus) reared near an industrial area of West Bengal, India. Arch Environ Contam Toxicol, 69(1): 32-43, doi: 10.1007/ s00244-015-0130-2

Khan BI, Solo-Gabriele HM, Townsend TG and Cai Y, 2006. Release of arsenic to the environment from CCA-treated wood. 1. Leaching and speciation during service. Environ Sci Tech, 40(3): 988-93, doi: 10.1021/es0514702

Klaassen CD, 1996. Heavy metal and heavy metal antagonists. In: Goodman and Gillmans the Pharmacological Basis of Therapeutics. PB Molinoff and R W Ruddon (eds) McGraw Hill, pp 1649-1671

Kozlowski H, Kolkowska P, Watly J, Krzywoszynska K and Potocki S, 2014. General aspects of metal toxicity. Curr Med Chem, 21(33): 3721-3740, doi: 10.2174/0929867321666140716093838

Krametter-Froetscher R, Tataruch F, Hauser S, Leschnik M, Url A et al., 2007. Toxic effects seen in a herd of beef cattle following exposure to ash residues contaminated by lead and mercury. Vet J, 174(1): 99-105, doi: 10.1016/j.tvj1.2006.03.008

Kumar N, Kumar S, Gupta R, Ramkaran and Ganguly A, 2019. Status of toxic heavy metals in cattle of Haryana. Haryana Vet, 58(1): 114-116

Lawton LJ and Donaldson WE, 1991. Lead-induced tissue fatty acid alterations and lipid peroxidation. Biol Trace Elem Res, 28: 157-161, doi: 10.1007/ BF02863075

Liu J, Goyer RA and Waalkes MP, 2008. Toxic effects of metals. Casarett and Doull's Toxicology : The Basic science of Poisons. $7^{\text {th }}$ Edn. New York McGraw-Hill, pp 931-979

López-Alonso M and Miranda M, 2020. Copper supplementation, a challenge in cattle. Animals, 10(10): 1890-1910, doi: 10.3390/ani10101890

López-Alonso M, Crespo A, Miranda M, Castillo C, Hernndez J et al., 2006. Assessment of some blood parameters as potential markers of hepatic copper accumulation in cattle, J Vet Diagn Invest, 18: 7175, doi: 10.1177/104063870601800109

Madejón P, Domínguez MT and Murillo JM, 2009. Evaluation of pastures for horses grazing on soils polluted by trace elements. Ecotoxicol, 18(4): 417428, doi: 10.1007/s10646-009-0296-3

Mahajan VK, Yadav RR, Dakshinkar NP, Dhoot VM, Bhojane GR et al., 2012. Influence of mercury fly ash on cattle reared nearby thermal power plant. Environ Monit Assess, 184(12): 7365-7372, doi: 10.1007/s10661-011-2505-9 
Maji C, Biswas S, Sarkar PK, Patra PH, Bandyopadhyay S et al., 2020. Evaluation of ameliorative effect of two selected plant drugs on experimentally induced arsenic toxicity in sheep. Environ Sci Pollut Res Int, 27(29): 36744-36753, doi: 10.1007/s11356020-09569-4

Makridis C, Svarnas C, Rigas N, Gougoulias N, Roka L et al., 2012. Transfer of heavy metal contaminants from animal feed to animal products. J Agric Sci Technol, A 2: 149-154

Mandal P, 2017. An insight of environmental contamination of arsenic on animal health. Emerg Contam, 3(1): 17-22, doi: 10.1016/ j.emcon.2017.01.004

Martin KP, Padilha VH, Damasceno TK, Souza MA, Silva E et al., 2020. Chronic poisoning in beef cattle in state of Mato Grosso, Braz Pequisa Vet Bras, 40: 651-661, doi: 10.1590/1678-5150-PVB-6526

Mecitoglu Z, Topal O, Kacar Y and Batmaz H, 2017. Comparing the effects of treatment with ammonium molybdate versus ammonium molybdate and phenoxy-2-methyl-2-propionic acid on liver functions in natural copper poisoning of sheep. Small Rumin Res, 150: 93-96, doi: 10.1016/ j.smallrumres.2017.03.010

Mennear JH, 1979. Cadmium toxicity. $1^{\text {st }}$ Ed, Marcel Dekker, INC, pp 29-40

Minervino AH, Barrêto Júnior RA, Ferreira RN, Rodrigues FA, Headley SA et al., 2009. Clinical observations of cattle and buffaloes with experimentally induced chronic copper poisoning. Res Vet Sci, 87(3): 473-478, doi: 10.1016/ j.rvsc.2009.05.002

Minervino AHM, López-Alonso M, Barrêto Júnior RA, Rodrigues FAML, Araújo CASC et al., 2018. Dietary zinc supplementation to prevent chronic copper poisoning in sheep. Animals (Basel), 8(12): 227, doi: 10.3390/ani8120227

Mishra AK, Sahu A, Kanwar S, Sharma D and Panigrahi AK, 2013. Mercury pollution in and around a chloralkali industry: A review. Ecoscan, 3: 349-366

Mondal D, Rahman MM, Suman S, Sharma P, Siddique AB et al., 2021. Arsenic exposure from food exceeds that from drinking water in endemic area of Bihar, India. Sci Total Environ, 754: 142082, doi: 10.1016/j.scitotenv.2020.142082

Murawski M, BydłonG, Sawicka-Kapusta K, Wierzchoś E, Zakrzewska M et al., 2006. The effect of long term exposure to copper on physiological condition and reproduction of sheep. Reprod Biol, 6(Suppl): 201-206

Nandi D, Patra, RC and Swarup D, 2005. Arsenic residues in hair samples from cattle in some arsenic affected areas of West Bengal, India. Bull Environ Contam Toxicol, 75(2): 251-256, doi: 10.1007/s00128-0050745-5

Newairy AA, El-Sharaky AS, Baldreldeen MM, Eweda SM and Sheweita SA, 2007. The hepatoprotective effects of selenium against cadmium toxicity in rats. Toxicol, 242(1-3): 23-30, doi: 10.1016/ j.tox.2007.09.001

Nicholson JK, Kendall MD and Osborn D, 1983. Cadmium and mercury: nephrotoxicity. Nature, 304(5927): 633-635, doi: 10.1038/304633a0

NRC (National Research Council), 2005. Mineral Tolerance of Animals. $2^{\text {nd }}$ Edn. The National Academic Press, Washington DC, USA

Oluokun JA, Fajimi AK, Adebayo AO and Ajayi FT, 2007. Lead and cadmium poisoning of goats raised in cement kiln dust polluted area. J Food Agric Environ, 5(1): 382-384

Orisakwe OE, Oladipo OO, Ajaezi GC and Udowelle NA, 2017. Horizontal and vertical distribution of heavy metals in farm produce and livestock around lead contaminated goldmine in Dareta and Abare, Zamfara State, Northern Nigeria. J Environ Public Health, 2017: 3506949, doi: 10.1155/2017/ 3506949

Patra RC, Swarup D, Sharma MC and Naresh R, 2006. Trace mineral profile in blood and hair from cattle environmentally exposed to lead and cadmium around different industrial units. J Vet Med A Physiol Pathol Clin Med, 53 (10): 511-517, doi: 10.1111/j.1439-0442.2006.00868.x

Patra RC, Rautray AK and Swarup D, 2011. Oxidative stress in lead and cadmium toxicity and its amelioration. Vet Med Int, 2011: 457327, doi: $10.4061 / 2011 / 457327$

Patra RC, Swarup D and Senapati SK, 1999. Effects of cadmium on lipid peroxides and superoxide dismutase in hepatic, renal and testicular tissue of rats. Vet Hum Toxicol, 41(2): 65-67

Patra RC, Swarup D, Naresh R, Kumar P, Nandi D et al., 2007. Tail hair as an indicator of environmental exposure of cows to lead and cadmium in different industrial areas. Ecotoxicol Environ Safty, 66(1): 127-131, doi: 10.1016/j.ecoenv.2006.01.005

Pérez-Carrera AL, Arellano FE and Fernández-Cirelli A, 2016. Concentration of trace elements in raw milk from cows in the southeast of Córdoba province, Argentina. Dairy Sci Technol, 96(5): 591-602, doi: 10.1007/s13594-016-0290-5

Pilarczyk R, Wójcik J, Czerniak P, Sablik P, Pilarczyk B et al., 2013. Concentration of toxic heavy metals 
and trace elements in raw milk of Simmental and Holstein Friesian cows from organic farm. Environ Monit Assess, 185(10): 8383-8392, doi: 10.1007/ s10661-013-3180-9

Rahimi E, 2013. Lead and cadmium concentrations in goat, cow, sheep, and buffalo milk from different regions of Iran. Food Chem, 136(2): 389-391, doi: 10.1016/j.foodchem.2012.09.016

Rahimzadeh MR, Rahimzadeh MR, Kazemi S and Moghadamnia AA, 2017. Cadmium toxicity and treatment: An update. Caspian J Intern Med, 8(3): 135-145, doi: 10.22088/cjim.8.3.135

Raj D and Maiti SK, 2019. Sources, toxicity and remediation of mercury: An essence review. Environ Monit Assess, 191(9): 566, doi: 10.1007/s10661019-7743-2

Rana T, Bera AK, Das S, Bhattacharya D, Bandyopadhyay S et al., 2010. Effects of chronic intake of arsenic contaminated water on blood oxidative stress indices in cattle in an arsenic affected zone. Ecotoxicol Enviorn Safety, 73(6): 1327-1332, doi: 10.1016/j.ecoenv.2010.06.002

Rana T, Sarkar S, Mandal T, Bhattacharyya K, Roy A et al., 2008. Contribution of arsenic from agricultural food chain to cow milk in highly arsenic prone zone in Nadia District of West Bengal in India. Int J Vet Med, 4(2): 1-6

Reis LS, Pardo PE, Camargos AS and Oba E, 2010. Mineral element and heavy metal poisoning in animals. J Med Med Sci, 1(12): 560-579

Rhind SM, Kyle CE and Owen J, 2005. Accumulation of potentially toxic metals in the liver tissue of sheep grazed on sewage sludge-treated pastures. Anim Sci, 81(1): 107-113, doi: 10.1079/ASC42120107

Rodríguez-Estival J, Barasona JA and Mateo R, 2012. Blood $\mathrm{Pb}$ and $\mathrm{d}$ - ALD inhibition in cattle and sheep from $\mathrm{Pb}$ - polluted mining area. Environ Pollut, 160: 118-124, doi: 10.1016/j.envpol.2011.09.031

Roth Z, 2017. Effect of heat stress on reproduction in dairy cows: insights into the cellular and molecular responses of the oocyte. Annu Rev Anim Biosci, 5: 151-170, doi: 10.1146/annurev-animal-022516022849

Sandu HS and Brar RS, 2003. A textbook of Veterinary Toxicology, 1st edn., Kalyani publishers, pp 81-114

Sathyamoorthy K, Sivaruban T and Barathy S, 2016. Assessment of heavy metal pollution and contaminants in the cattle meat. J Ind Pollut Control, 32(1): 350-355

Schmitz DG, 2007. Toxins affecting the urinary system. Vet Clin North Am Equine Pract, 23(3): 677-690, doi: 10.1016/j.cveq.2007.09.001
Sharpe RT and Livesey CT, 2006. Lead poisoning in cattle and its implications for food safety. Vet Rec, 159(3): 71-74, doi: 10.1136/vr.159.3.71

Singh M, Ranvir S, Sharma R, Gandhi K and Mann B, 2019. Assessment of contamination of milk and milk products with heavy metals. Indian J Dairy Sci, 72(6): 608-615, doi: 10.33785/ IJDS.2019.v72i06.005

Singh T, 2018. Therapeutic management of lead poisoning in a cow. Intas Polivet, 19(1): 89-90

Slivinska LG, Shcherbatyy AR, Lukashchuk BO and Gutyj BV, 2020. The state of antioxidant protection system in cows under the influence of heavy metals. Regul Mech Biosyst, 11(2): 237-242, doi: 10.15421/022035

Smith GM and White CL, 1997. A molybdenum-sulfurcadmium interaction in sheep. Aust J Agric Res, 48: 147-154, doi: 10.1071/A96092

Spiller HA, 2018. Rethinking mercury: the role of selenium in the patho-physiology of mercury toxicity. Clin Toxicol, 56(5): 313-326, doi: 10.1080/15563650.2017.1400555

Spiller HA, Hays HL and Casavant MJ, 2021. Rethinking treatment of mercury poisoning: the roles of selenium, acetylcysteine and thiol chelators in the treatment of mercury poisoning: A narrative review. Toxicol Comm, 5(1); 19-59, doi: 10.1080/ 24734306.2020.1870077

Suttle NF, 2012. Copper imbalances in ruminants and humans: unexpected common ground. Adv Nutr, 3(5): 666-674, doi: 10.3945/an.112.002220

Swarup D and Dwivedi HP, 2011. Animal health risks due to inorganic chemical pollutants. In. Environmental Security: Human and Animal Health. Sudhi Ranjan Garg. Ed. IBDC Publishers, pp 25-38

Swarup D and Dwivedi SK, 2002. Environmental pollution and effect of lead and fluoride on animal health. Indian Council of Agricultural Research, New Delhi, pp 68-106

Swarup D, Naresh R, Varshney VP, Balagangatharathilagar M, Kumar P et al., 2007. Changes in plasma hormones profile and liver function in cows naturally exposed to lead and cadmium around different industrial areas. Res Vet Sci, 82(1): 16-21, doi: 10.1016/j.rvsc.2006.05.002

Swarup D, Patra RC, Naresh R, Kumar P, Shekhar P et al., 2006. Lowered blood copper and cobalt contents in goats reared around lead-zinc smelter. Small Rumin Res, 63: 309-313, doi: 10.1016/ j.smallrumres.2005.03.011

Swarup D, Dwivedi SK and Patra RC, 2000. Industrial 
pollution and animal health- A review. Vet Practitioner, 1: 75-94

Swarup D, Patra RC, Naresh R, Kumar P and Shekhar P, 2005. Blood lead levels in lactating cows reared around polluted localities; transfer of lead in to milk. Sci Total Environ, 347(1-3): 106-110, doi: 10.1016/ j.scitotenv.2004.12.055

Takahashi T and Shimohata T, 2019. Vascular dysfunction induced by mercury exposure. Int J Mol Sci, 20(10): 2435; doi: 10.3390/ijms20102435

Tchounwou PB, Yedjou CG, Patlolla AK and SuttonDJ, 2012. Heavy metal toxicity and the environment. Exp Suppl, 101: 133-164, doi: 10.1007/978-3-7643-8340-4_6

Thompson LJ, 2012. Lead. In: Veterinary Toxicology: Basic and Clinical Principles. RC Gupta Ed. Academic Press, pp 522-526

Tokarnia CH, Döbereiner J, Peixoto P and Moraes SS, 2000. Outbreak of copper poisoning in cattle fed poultry litter. Vet Hum Toxicol, 42(2): 92-95

Traverso SD, Loretti AP, Donini MA and Driemeier D, 2004. Lead poisoning in cattle in southern Brazil. Arq Bras Med Vet Zootec, 56(3): 418-421, doi: 10.1590/S0102-09352004000300023

Tunegova M, Toman R and Tanèin V, 2016. Heavy metals-environmental contaminants and their occurrence in different types of milk. Slovak $\mathbf{J}$ Anim Sci, 49(3): 122-131

Uppal JM, 2004. Heavy metals. In Textbook of Veterinary Toxicology, $1^{\text {st }}$ Ed. CBS Publishers and
Distributors, New Delhi, pp 137-138

Verma J, Kumari S and Dhasmana A, 2020. Toxic effect of lead on earth's life. Int J Innov Res Technol, 7(1): 673-676

Volkov R and Samigullin D, 2020. Heavy metal uptake and transition across the links of soil-plant-animalfood chain. IOP Conference Series: Earth and Environmental Science, Volume 715, 2nd International Conference on Agriculture and Rural Development, Serang City, Banten, Indonesia, doi: 10.1088/1755-1315/715/1/012023

Vromman V, Saegerman C, Pussemier L, Huyghebaert A, De Temmerman L et al., 2008. Cadmiium in the food chain near non-ferrous metal production sites. Food Addit Contam Part A Chem Anal Control Expo Risk Assess, 25(3): 293-301, doi: 10.1080/ 02652030701509980

Yang L, Zhang Y, Wang F, Luo Z, Guo S et al., 2020. Toxicity of mrcury: Molecular evidence. Chemosphere, 245: 125586, doi: 10.1016/ j.chemosphere.2019.125586

Yeotikar PV, Nayyar S, Singh C, Mukhopadhyay CS, Kakkar SS et al., 2018. Seasonal variation in oxidative stress markers of Murrah buffaloes in heavy metal exposed areas of Ludhiana. Indian J Anim Res, 53(10): 1310-1315, doi: 10.18805/ijar.B-3643

Yost KJ, 1984. Cadmium, the environment and human health, an overview. Experientia, 40(2): 157-164, doi: $10.1007 / \mathrm{BF} 01963579$

Received - 03.09.2021, Accepted - 07.11.2021, Published - 01.12.2021

Section Editors: Prof. S. Biswas and Dr. A. K. Das, Members, Editorial Board 